\title{
USING DIAZOTROPHIC ENDOPHYTES IN IMPROVING SOME CEREAL PRODUCTION UNDER SALINE DESERT CONDITION
}

\author{
Amal M. Omer \\ Department of Soil Fertility and Microbiology, Desert Research \\ Center, El-Matareya, Cairo, Egypt \\ E-mail: amal_omaram@yahoo.com
}

\begin{abstract}
$\mathrm{T}$ he present study was conducted to develop the bacterial consortia of salt tolerant endophytic diazotrohs. Forty three endophytic bacterial isolates were assayed for their nitrogen fixation and hormone production at different $\mathrm{NaCl}$ concentrations. All selected endophytic Azotobacter and Azospirillum isolates exhibited nitrogenase activities ranged from 15.4 to 96.1 n.mole $\mathrm{C}_{2} \mathrm{H}_{4} / \mathrm{ml} / \mathrm{h}$, indol acetic acid ranged from 31 to $168 \mu \mathrm{g} / \mathrm{ml}$ and gibberellins from 2.8 to $29.4 \mu \mathrm{g} / \mathrm{ml}$ at $\mathrm{NaCl}$ ranged from 1 to $5 \%$. Vital staining technique of wheat and barley seedlings revealed the presence of pink to purple stained endophytic bacteria in their root tissues. Different bacterial consortia were developed from the highly efficient endophytic nitrogen fixers. Two highly efficient bacterial endophytic consortia at $1 \% \mathrm{NaCl}$ were selected for further lab and field experiments. The two bacterial consortia were investigated for their nitrogen fixation activities and indole acetic acid (IAA) production under different concentrations of salt. The obtained results revealed a dramatic decrease in the amount of fixed $\mathrm{N}$ with increasing the salt content from 1 to $10 \%$ $\mathrm{NaCl}$ for both consortia. The consortium of barley endophytes exhibited the highest IAA production at $5 \% \mathrm{NaCl}$, while that of wheat exhibited the maximum IAA at $1 \% \mathrm{NaCl}$.

Two field experiments conducted at Ras Sudr Experimental Station showed that inoculation of wheat and barley seeds with endophytic bacterial consortia significantly increased all the growth parameters, nitrogen content and uptake of two plants under salinity stress. Also, bacterial consortium of wheat endophytes along with half dose of nitrogen achieved the highest significant wheat and barley yields. Inoculation with endophytic bacterial consortia had a positive effect on the count of bacterial nitrogen fixers and dehydrogenase in the rhizoshere.
\end{abstract}

Keywords: endophytes, consortia, salt stress, wheat, barley 
Nitrogen is one of the important limiting factors for plant growth under different environmental conditions. Despite abundance of atmospheric nitrogen $(78 \%)$, it cannot be utilized directly by the plant for growth and metabolism as it must be reduced to ammonia by a process called nitrogen fixation.

Salinity of soil or irrigation water can interfere with nitrogen nutrition in a direct or indirect way, usually at assimilation pathway of the inorganic nitrogen compounds. Assimilation and uptake of nitrate and ammonium are inhibited by higher concentrations of $\mathrm{Na}^{+}, \mathrm{K}^{+}$and $\mathrm{Mg}^{2+}$ to a different extent (Wolfram, 2012). Over fertilization of $\mathrm{N}$ may contribute to salinization of soil and so increase the negative impacts of soil salinity on plant performance (Villa-Castorena et al., 2003). In addition, where high amounts of salts are present in soils, the potential for $\mathrm{NO}_{3}$ leaching may increase because plants under salinity stress cannot absorb or utilize the applied $\mathrm{N}$ as efficiently as the plants not subjected to salt stress (Pessarakli and Tucker, 1988 and Bowman et al., 2006). Further, as the salinity of irrigation water rises, the leaching fraction must be increase to control root zone salinity.

Application of industrially manufactured nitrogen fertilizers is one of the most popular way to provide plants with its nitrogen requirements to attain high crop productivity, but the excessive use of inorganic fertilizers might cause ground water contamination and environmental hazards, in addition to their high costs (Lee et al., 1992). Therefore, substitution of inorganic fertilizers with biofertilizers as nitrogen-fixers (Diazotrophs) is considered to be the most potential ways to provide fixed form of nitrogen to the plants with low cost and safety hazards.

Diazotrophs are prokaryotes (bacteria and cyanobacteria) and archeans capable of assimilating and fixing atmospheric nitrogen $\left(\mathrm{N}_{2}\right)$ through natural means. They make use of iron-molybdenum or vanadium nitrogenase systems to fix atmospheric nitrogen and produce new nitrogen compounds that are more readily available for use by other organisms, such as plants.

A great number of nitrogen-fixing microorganisms, called nitrogenfixing free living endophytes, inhabit both root and stem of plants such as Azospirillum, Gluconacetobacter diazotrophicus, Azoarcus, Beijerinckia, Enterobacter, Klebsiella, Pseudomona, Azorhizobium, Herbaspirillum and Azotobacter and they are more effective than their rhizospheric counterparts in terms of benefiting their host through nitrogen fixation as they can provide fixed nitrogen directly to their host (Cocking, 2003). Moreover, endophytic bacteria are less vulnerable for competition with other soil microbes for nutrients resources and remain protected to various abiotic and biotic stresses (Reinhold-Hurek and Hurek, 1998). In addition to diazotrophy, endophytic bacteria may enhance plant growth through one or more 
mechanisms, which include phytohormone production, siderophore production, induced systemic tolerance and biocontrol potential. It has been suggested that bacteria colonizing the plant interior might interact more closely with the host, with less competition for carbon sources and a more protected environment for $\mathrm{N}_{2}$ fixation. For hormonal production, salinity inhibits the synthesis of phytohormones in plants and perturbs the hormonal balance of plants (Figueiredo et al., 2008). The exogenous application of phytohormones as auxins (Khan et al., 2004), gibberellins (Afzal et al., 2005) and cytokinins (Gul et al., 2000) mitigate salt stress and stimulate plant root and shoot growth under stress. Phytohormone producing rootassociated bacteria might supply additional IAA into the rhizosphere and stimulate the growth of lateral roots and root hairs (Egamberdieva, 2009 and Bano et al., 2013).

Cereals are the grain-producing crops that provide more than 50 percent of human energy and protein needs (Stoskopf, 1985). They have been the staple food for most human societies for over 10,000 years due to specific features such as ease of growth, storage and transport, these crops have a number of adaptations, which enable them to survive and grow well in the particular environmental conditions as drought and salinity (Calderini and Slafer, 1998) but salinity stress directly affects their production and quality (Khush, 1999).

The aims of this study were the isolation, identification and evaluation of diazotrophic endophytes consortia associated with some cereal crops grown in saline soil and to determine their impact on the productivity of these crops.

\section{MATERIALS AND METHODS}

\section{Isolation of Endophytic Nitrogen Fixing Bacteria}

Roots and stems of different cereals as wheat and barley plants grown in different locations of salt affected soils as Ras Sudr, Sahl Eltina and El Maghara were randomly collected and washed with tap water, the roots or stems were immersed 2 times in $70 \%$ ethanol for three minutes, immersed twice in $4 \%$ aqueous solution of sodium hypochlorite for 5 minutes and flaming. Approximately $1 \mathrm{~cm}$ was then removed from each end, homogenized under sterile conditions, with a mortar and pestle in phosphatebuffered solution, and the resulting juices were plated on Ashby's and semisolid $\mathrm{N}$-free media amended with 1. 3, 5 and $7 \% \mathrm{NaCl}$ (About $1 \mathrm{ml}$ of the plant juices was serially diluted up to $10^{-3}$ using sterile $10 \mathrm{mM}$ potassium phosphate buffer, $\mathrm{pH} 7$ ) and kept in an incubator at $28^{\circ} \mathrm{C}$ for 7 days (Denise et al., 2002). After incubation, colonies originating were subjected to microscopic investigation and about 43 bacterial colonies were selected for further investigations. 


\section{Selection of the Most efficient Endophytic Nitrogen Fixing Bacteria}

The ability of 43 endophytic bacterial isolates (twenty one grown on Ashby's and twenty two on semisolid N-free media) to fix nitrogen and hormone production were assayed.

Nitrogen fixation ability was estimated by the following:

- Acetylene reduction technique using gas chromatography (Hewlett Packard chromatography model HP 6890 GC) fitted with dual flame detector and $150 \mathrm{~cm} \times 0.4 \mathrm{~cm}$ diameter stainless still column fitted with propak X R100-120 mesh according to methods of Hardy et al. (1973) and Somasegaran and Hoben (1985). The results were presented as $n$ mole $\mathrm{C}_{2} \mathrm{H}_{4} / \mathrm{ml}$ culture $/ \mathrm{h}$.

- Determination of nitrogen fixing capacity in pure culture; Bacterial isolates were grown on their specific media for three days, noninoculated media served as control. Afterwards, the concentration of nitrogen in each liquid culture was measured by digestion and subsequent measurement by the Kjeldahl method (Bremner and Mulvaney, 1982). The quantities of nitrogen present in duplicate cultures after deducting the average of duplicate control were reported.

Production of some hormones by bacterial isolates was estimated as following:

- Indole acetic acid (IAA) production in growing media supplemented with L-tryptophan $(1 \mathrm{~g} / \mathrm{L})$ spectrophotometerically using Salkowski reagent as described by Ehmann (1977).

- Gibberellins production in ethyl acetate extraction using $\mathrm{HCl}$ and Folin reagent according to the method described by Graham and Henderson (1960).

\section{Development of Efficient Endophytic Bacterial Consortia}

Different bacterial consortia were developed, each one consist of three highly effective (wheat or barley) endophytes. Each consortium was prepared from three highly efficient endophytes as following:

The single selected isolates were recombined into a bacterial consortium by making individual bacterial suspensions with equal OD 600, then $20 \mathrm{ml}$ of each suspension was added to $100 \mathrm{ml}$ of fresh basal medium and incubated for 48 hours for subsequent evaluation. Two highly efficient bacterial consortia were selected based on their in vitro nitrogen fixation and IAA production at $1 \% \mathrm{NaCl}$ (only the data of two selected consortia were tabulated). The first one consisted of wheat endophytes, while the second consisted from barley endophytes. The isolates in each consortia were identified according to their morphological and physiological characteristics. 


\section{Visualization and Enumeration of Endophytic Bacteria in Seedling Roots}

One $\mathrm{ml}$ of each of the two selected consortia (each containing $10^{7}$ $10^{8} \mathrm{cfu} \mathrm{m}^{-1}$ ) was inoculated in $60 \mathrm{ml}$ of Hoagland's medium (Hoagland and Arnon, 1950) with all salts, micronutrients and $0.6 \%$ agar were placed in 100 $\mathrm{ml}$ capacity test tube. The medium was adjusted at $1 \% \mathrm{NaCl}$ concentration, which is suitable for all bacterial isolates. After solidification, three surface sterilized wheat or barley seeds, as target plants, were transferred to the test tube and incubated in a growth chamber at $28^{\circ} \mathrm{C}$ for 3 weeks. The treatments were conducted separately, where the seeds of wheat and barley have been inoculated with consortium of each wheat endophytes (Consortium W) and barley endophytes (Consortium B), while seeds inoculated with distilled water was served as control

Each experiment was performed at least twice. At the end of the experiment, seedlings biomass was recorded and endophytic bacterial counts were detected in the roots of either wheat or barley. Microscopic examination and localization of endophytic bacteria within plant by vital staining technique was performed using the protocol of Pathak et al. (2009). Breifly, the $0.15 \mathrm{~g}$ 2,3,5-triphenyltetrazolium chloride (TTC) was added to sterile $50 \mathrm{mM}$ malate potassium phosphate buffer $(100 \mathrm{ml} 50 \mathrm{mM}$ potassium phosphate buffer ( $\mathrm{pH}-7)$ and $0.0625 \mathrm{~g}$ malic acid) in aseptic condition. Surface-sterilized of plant segments were dipped into $20 \mathrm{ml}$ of the above sterile TTC solution and incubated overnight at $30^{\circ} \mathrm{C}$. TTC-treated cross sections were placed on glass microscopic slides and covered with a glass cover slip. Sections were examined under light microscope at $100 x$ magnification.

\section{Effect of Salinity on Nitrogen Fixing Capacity and IAA Secretion of Bacterial Endophytic Consortia}

The two bacterial consortia were investigated for their nitrogen fixation activities and indole acetic acid (IAA) production under different concentrations of salt ranging from 1 to $10 \% \mathrm{NaCl}$.

\section{Field Experiments}

Two field experiments were conducted at Ras Sudr Experimental Station, South Sinai (saline sandy loam soil) during 2015/16 to evaluate the application of two endophytic bacterial consortia on the growth and productivity of wheat (Sakha 94) and barley (Giza 126). The experiments were designed in a completely randomized design with three replicates. Grains were moistened in carboxy methyl cellulose solution (1\%) before application of bacterial inoculum as a single strain and the inoculated seeds were dried in shade before sowing (Samasegaran et al., 1982), untreated control seeds were maintained. Phosphate fertilizer as super phosphate $\left(15.5 \% \quad \mathrm{P}_{2} \mathrm{O}_{5}\right)$ was added at a rate of $150 \mathrm{~kg} /$ feddan during seed bed 
preparation, $100 \mathrm{~kg}$ of potassium sulphate $\left(50.0 \% \mathrm{~K}_{2} \mathrm{SO}_{4}\right)$ was added at flowering stage, whereas nitrogen fertilizer was applied as ammonium sulfate $(20.5 \% \mathrm{~N})$ at rate of $250 \mathrm{~kg} /$ feddan for full of recommended dose and $125 \mathrm{~kg}$ /feddan for half of recommended dose (1/3 of the amount was incorporated in dry soil before sowing, $1 / 3$ was added one month after sowing and the rest was added one week pre flowering stage). The investigated soil was irrigated with saline water (EC about $7.94 \mathrm{dSm}^{-1}$ ), which is considered to be the main source of irrigation water in this area. Some physical and chemical properties of the soil and the average characteristics of chemical analysis of well irrigation water are presented in table (1).

Table (1). Some physical and chemical properties of the studied soil and the chemical analysis of irrigation water.

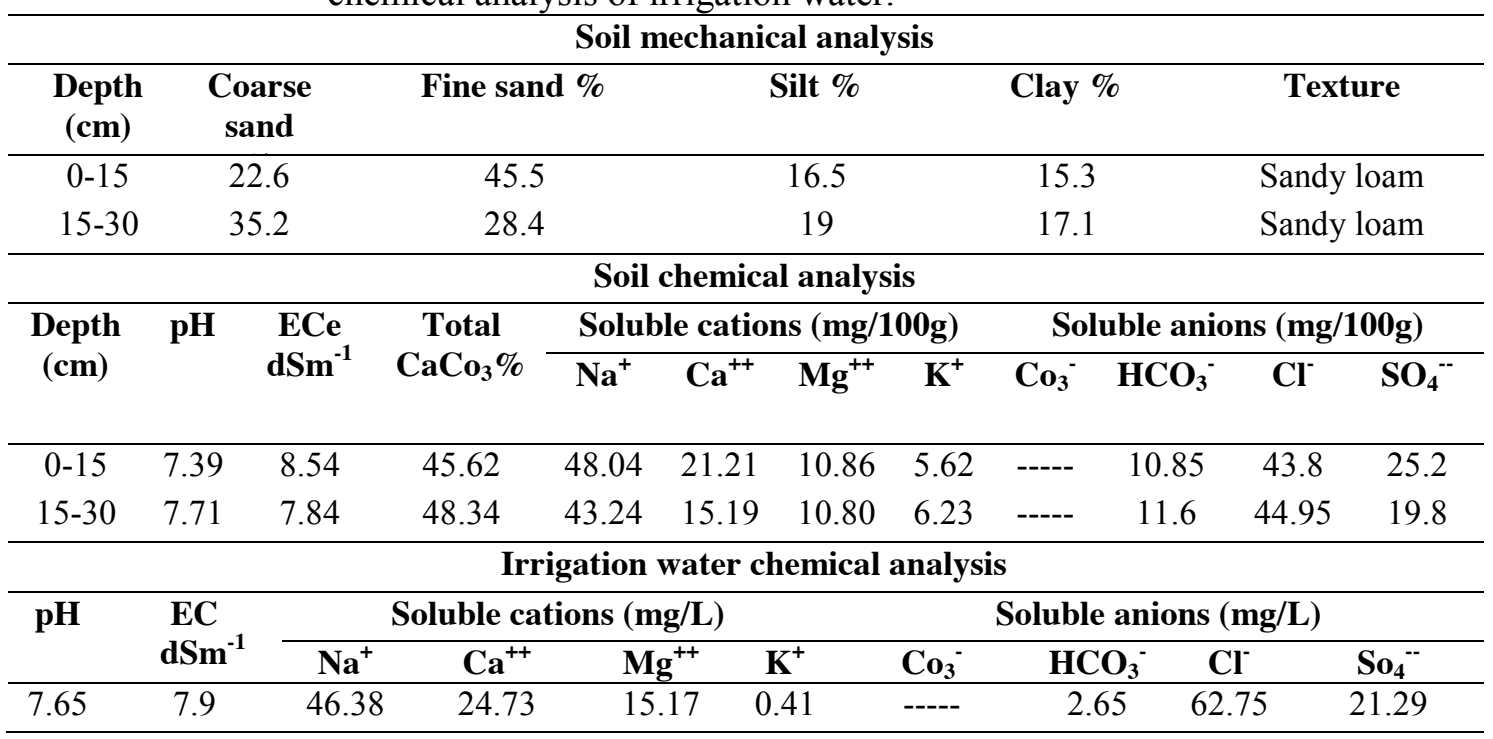

After harvesting, the following traits were estimated: Plant height, number of spikes/plant, 1000-grain weight, grain yield/plant, straw yield/plant and biological yield. Chemical analysis of wheat and barley grains were conducted after harvest for determination of nitrogen content and uptake in straw and seed and $\mathrm{N}$ available in the rhizosphere regions as indicated by Bremner and Mulvaney (1982).

For microbiological analysis, total microbial count and populations of Azotobacter and Azospirillum in the rhizosphere samples were estimated using nutrient, Ashby's and Doberiner media, respectively. Soil dehydrogenase activity ( $\mu \mathrm{g} \mathrm{TPF} / \mathrm{g}$ dry soil/24 h) was analyzed by the reduction of triphenyl tetrazolium chloride (TTC) to triphenyl formazan (TPF) as described by Friedel et al. (1994). 


\section{Statistical Analysis}

The obtained data were subjected to statistical analysis using the method described by Snedecor and Cochran (1990). The least significant difference (L.S.D.) was used to differentiate means according to Waller and Duncan (1969).

\section{RESULTS AND DISCUSSION}

\section{Isolation and Selection of the Most Effective Salt Tolerant Endophytes}

A total of 43 endophytic nitrogen fixers bacteria were obtained and coded according to their host plants and location from which they were isolated. Only data of the highly potential endophytes were recorded as shown in table (2). The most effective six Azotobacter and eight Azospirillum isolates were selected on the basis of their plant growth promoting properties. As the isolation of the nitrogen fixer endophytes were conducted at different degree of salinity, it is clear from the results that Azospirillum spp. were isolated up to $5 \% \mathrm{NaCl}$, while Azotobacter spp. were isolated up to $3 \%$ salinity only, which means that the Azospirillum isolates were more tolerant to salinity than Azotobacter isolates. Ravikumar et al. (2002) found Azospirillum brasilense could tolerate the concentration of 3\% $\mathrm{NaCl}$ in the growing medium. Nitrogen fixation capacity of the isolates can be determined either by measuring of nitrogenase activity or amount of nitrogen fixed in the growing media. Nitrogenase activities ranged from 96.1 to 22.7 n.mole $\mathrm{C}_{2} \mathrm{H}_{4} / \mathrm{ml} / \mathrm{h}$ at 1 and $3 \% \mathrm{NaCl}$ for Azotobacter isolates and from 52.1 to 15.4 n.mole $\mathrm{C}_{2} \mathrm{H}_{4} / \mathrm{ml} / \mathrm{h}$ at salinity ranged froml to $5 \% \mathrm{NaCl}$ concentrations for Azospirillum isolates. The same was recorded for the quantity of nitrogen fixed in growth media. At $1 \% \mathrm{NaCl}$, Azotobacter isolates exhibited higher nitrogen fixation ability than Azospirillum ones, while Azospirillum isolates were more efficient at higher salinity (3 and 5\% $\mathrm{NaCl}$ ). The ability of an endophyte to fix atmospheric nitrogen within a host has been proved using different approaches; ARA, $\mathrm{N}_{15}$ isotope dilution experiments, $\mathrm{N}_{15}$ reduction assay or $\mathrm{N}_{15}$ natural abundance assays (Dalton and Kramer, 2006). The variability of the nitrogenase activity of Azospirillum has been observed previously in vitro by Han and New (1998), with ARA varying from 0 to $155 \mathrm{nmol}$ of $\mathrm{C}_{2} \mathrm{H}_{4} \mathrm{mg}$ protein ${ }^{-1} \mathrm{~h}^{-1}$, in pure cultures of A. lipoferum and A. brasilense obtained from soils of different regions. In another study, the nitrogenase activity of Azospirillum isolates ranged from 17.6 to $49.6 \mathrm{nmol} \mathrm{C}_{2} \mathrm{H}_{4} \mathrm{ml}^{-1} \mathrm{~h}^{-1}$ being higher in cultures of $A$. brasilense than for A. lipoferum isolates (Mascarua et al., 1998).

For hormone production, all selected endophytic nitrogen fixers achieved different activities of IAA ranging from 31 to $168 \mu \mathrm{g} / \mathrm{ml}$ and gibberellins from 2.8 to $29.4 \mu \mathrm{g} / \mathrm{ml}$ at different salt concentrations ranged from 1 to $5 \% \mathrm{NaCl}$ concentrations. Beside fixing $\mathrm{N}$, associative and 
endophytic diazotrophic bacteria produce plant growth hormones such as auxin and gibberellins (Baca and Elmerich, 2007 and Spaepen et al., 2007). Under saline conditions, seed germination, growth and grain yield of wheat has been improved by application of gibberellic acid producing bacteria (Kumar and Singh, 1996).

Table (2). The performance of endophytic bacteria as nitrogen fixer and hormone producers.

\begin{tabular}{|c|c|c|c|c|c|c|c|c|}
\hline \multicolumn{5}{|c|}{ Bacterial characteristics } & \multicolumn{2}{|c|}{ Nitrogen fixation } & \multicolumn{2}{|c|}{ Hormone production } \\
\hline $\begin{array}{c}\text { Bacteria } \\
\text { spp. }\end{array}$ & $\begin{array}{c}\text { Salinity } \\
\%\end{array}$ & $\begin{array}{l}\text { Location } \\
\text { of isolates }\end{array}$ & $\begin{array}{c}\text { Plant } \\
\text { host }\end{array}$ & Code & $\begin{array}{c}\text { Fixed } \\
\text { nitrogen } \\
(\text { ppm) }\end{array}$ & $\begin{array}{c}\text { Nitrogenase } \\
\left(\text { n.moleC }{ }_{2} H_{4}\right. \\
/ / \mathrm{ml} / \mathrm{h})\end{array}$ & $\begin{array}{c}\text { IAA } \\
(\mu \mathrm{g} / \mathrm{ml})\end{array}$ & $\begin{array}{l}\text { Gibberellins } \\
(\mu \mathrm{g} / \mathrm{ml})\end{array}$ \\
\hline \multirow{6}{*}{ 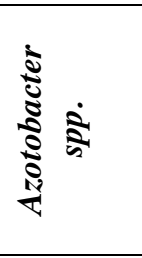 } & \multirow{4}{*}{1} & Ras Sudr & Wheat & RW1 & $97 \mathrm{a}$ & 59.4 & $31 \mathrm{~h}$ & $4.5 \mathrm{gh}$ \\
\hline & & Sahl Eltina & Wheat & SW1 & $102 \mathrm{a}$ & 96.1 & $164 \mathrm{a}$ & $29.4 b$ \\
\hline & & El Maghara & Barley & MB1 & $98 \mathrm{a}$ & 47.8 & $116 \mathrm{c}$ & $18.9 \mathrm{~d}$ \\
\hline & & Ras Sudr & Barley & RB1 & $85 b$ & 63.6 & $168 \mathrm{a}$ & $9.7 \mathrm{f}$ \\
\hline & \multirow{2}{*}{3} & Sahl Eltina & Barley & SB3 & $76 \mathrm{c}$ & 49.3 & $51 \mathrm{~g}$ & $17.8 \mathrm{~d}$ \\
\hline & & El Maghara & Wheat & MW3 & $41 \mathrm{f}$ & 22.7 & $86 f$ & $6.4 \mathrm{~g}$ \\
\hline \multirow{8}{*}{ 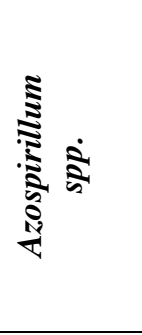 } & \multirow{3}{*}{1} & Sahl Eltina & Barley & SB1 & $63 d$ & 52.1 & $108 \mathrm{~d}$ & $12.9 \mathrm{e}$ \\
\hline & & Ras Sudr & Wheat & RW1 & $42 \mathrm{f}$ & 21.4 & $98 \mathrm{e}$ & $2.8 \mathrm{~h}$ \\
\hline & & El Maghara & Wheat & MW1 & $51 \mathrm{e}$ & 19.2 & $86 f$ & $25.3 \mathrm{c}$ \\
\hline & \multirow{3}{*}{3} & Ras Sudr & Wheat & RW3 & $87 \mathrm{~b}$ & 33.4 & 106de & $43.7 \mathrm{a}$ \\
\hline & & Ras Sudr & Barley & RB3 & $64 d$ & 15.4 & $46 \mathrm{~g}$ & $11.3 \mathrm{e}$ \\
\hline & & El Maghara & Barley & MB3 & $67 d$ & 18.9 & $86 f$ & $26.3 \mathrm{c}$ \\
\hline & \multirow{2}{*}{5} & Ras Sudr & Barley & RB5 & $77 \mathrm{c}$ & 29.5 & $147 b$ & $10.7 \mathrm{ef}$ \\
\hline & & Sahl Eltina & Barley & SB5 & $66 \mathrm{~d}$ & 19.8 & $102 d$ & $9.8 \mathrm{f}$ \\
\hline \multicolumn{2}{|c|}{ L.S.D. $0.05 \%$} & & & & 9.31 & - & 9.03 & 2.62 \\
\hline
\end{tabular}

For every variable, different symbols means there is a significant difference

\section{Selection of the Highly Efficient Endophytic Bacterial Consortia}

Among different endophytic bacterial consortia developed, two highly effective consortia were selected on the basis of their activity in nitrogen fixation and IAA production as in table (3). The first one namely consortium $\mathrm{B}$ is composed of two Azospirillum brasilense and one Azotobacter chroococcum strains isolated from different barley plants cultivated in Ras sudr, Sahl Eltina and Elmaghara. For consortium W, it composed of two Azotobacter chroococcum and one Azospirillum brasilense strains isolated from different wheat plants cultivated in Sahl Eltina and Ras sudr. 
Table (3). Performance of the highly efficient endophytic bacterial consortia in nitrogen fixation and IAA production.

\begin{tabular}{|c|c|c|c|c|}
\hline \multicolumn{5}{|c|}{ Bacterial consortia characteristics } \\
\hline $\begin{array}{l}\text { Consortia } \\
\text { Name }\end{array}$ & $\begin{array}{c}\text { Isolates in } \\
\text { each } \\
\text { consortium }\end{array}$ & $\begin{array}{l}\text { Identification of bacteria } \\
\text { in consortia }\end{array}$ & $\begin{array}{c}\text { Fixed nitrogen } \\
(\text { ppm) } \\
\text { at } \% \mathrm{NaCl}\end{array}$ & $\begin{array}{c}\text { IAA } \\
(\mu \mathrm{g} / \mathrm{ml}) \\
\text { at } 1 \% \mathrm{NaCl}\end{array}$ \\
\hline $\begin{array}{c}\text { Consortium } \\
\text { B }\end{array}$ & $\begin{array}{l}\text { RB5 } \\
\text { SB5 } \\
\text { MB1 }\end{array}$ & $\begin{array}{l}\text { Azospirillum brasilense } \\
\text { Azospirillum brasilense } \\
\text { Azotobacter chroococcum }\end{array}$ & 94 & 156 \\
\hline $\begin{array}{c}\text { Consortium } \\
\text { W }\end{array}$ & $\begin{array}{l}\text { SW1 } \\
\text { RW1 } \\
\text { RW3 }\end{array}$ & $\begin{array}{c}\text { Azotobacter chroococcum } \\
\text { Azotobacter chroococcum } \\
\text { Azospirillum brasilense }\end{array}$ & 97 & 209 \\
\hline
\end{tabular}

\section{Visualization and Enumeration of Endophytic Bacteria in Seedling Roots}

Staining of transverse sections of both barley and wheat roots inoculated with endophytes in sterile 2, 3, 5-Triphenyl tetrazolium chloride (TTC) revealed the presence of pink to purple stained bacteria in these root tissues as in fig. (1) upon microscopic examination. The actively respiring (viable) bacterial cells inside the surface-sterilized root tissues utilize malic acid as carbon source and reduce (TTC) to form water insoluble formazans, as discrete dark red to purple granules in the cells. These stained bacterial cells could be visualized by light microscopy as indicated by Patriquin and Dobereiner (1978). As recorded by Thekkiniath et al. (2010), ten strains of Azotobacter chroococcum exhibited ability to invade endorhizosphere as shown in microscopic observations due to higher production of cellulose, pectinase and induced defense enzymes in the host plant.

After three weeks of wheat and barley planted on Hoagland's medium, seedling biomass and endohytic bacterial count in the seedling roots have been detected. As in table (4), inoculation of seeds with endophytic bacteria had a positive effect on their counts inside the roots, consortium $\mathrm{W}$ recorded the highest entophytic bacterial counts in both wheat and barley roots regardless the type of plants inoculated. The same trend was recorded for the seedling biomass that inoculation with endophytic consortia increased the seedling biomass of wheat by 57.7 and $46.1 \%$ and of barley by 55.9 and $38.2 \%$ for consortium $\mathrm{W}$ and consortium $\mathrm{B}$, respectively. This meant that consortium $\mathrm{W}$ was more effective than consortium $\mathrm{B}$ for both wheat and barley. From these data, it can be concluded that the efficiency of the endophytic consortia depends on the activities of their bacteria and not to the host type. Concerning to plant type, endophytic bacterial counts and biomass of barley seedling was higher than that of wheat seedlings at $1 \%$ $\mathrm{NaCl}$ concentration, which indicated that barley seedlings are more resistant to salinity than wheat seedlings. 


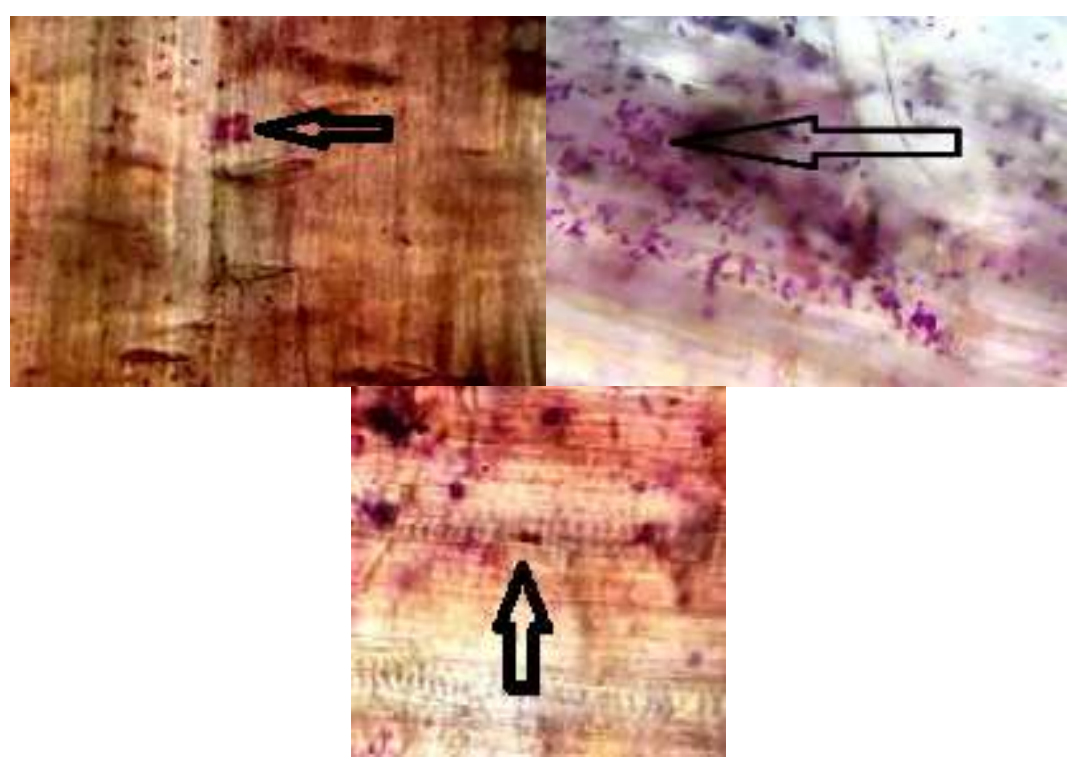

Fig. (1). Light micrograph $100 \mathrm{x}$ of transverse sections of wheat and barley roots treated with TTC showing association of bacterial cells in root sections as red spot.

Table (4). Effect of bacterial consortia on seedling biomass and endopytic bacterial counts in their roots at $1 \% \mathrm{NaCl}$.

\begin{tabular}{lcclcc}
\hline & Wheat & Barley & \\
\hline Treatments & $\begin{array}{c}\text { Seedling } \\
\text { biomass } \\
(\mathbf{g})\end{array}$ & $\begin{array}{c}\text { Endophytic } \\
\text { bacterial } \\
\text { counts } \\
* \mathbf{1 0}^{\mathbf{3}} \mathbf{C F U} / \mathbf{g} \\
\text { root }\end{array}$ & Treatments & $\begin{array}{c}\text { Seedling } \\
\text { Biomass } \\
(\mathbf{g})\end{array}$ & $\begin{array}{c}\text { Endophytic } \\
\text { Bacterial } \\
\text { counts } \\
* \mathbf{1 0}^{\mathbf{3}} \mathbf{C F U} / \mathbf{g} \\
\text { root }\end{array}$ \\
\hline Control & $0.26 \mathrm{a}$ & $3.1 \mathrm{~b}$ & Control & $0.34 \mathrm{a}$ & $4.7 \mathrm{~b}$ \\
Consortium W & $0.41 \mathrm{a}$ & $290.0 \mathrm{a}$ & Consortium W & $0.53 \mathrm{a}$ & $310.0 \mathrm{a}$ \\
Consortium B & $0.38 \mathrm{~b}$ & $265.0 \mathrm{a}$ & Consortium B & $0.47 \mathrm{~b}$ & $306.0 \mathrm{a}$ \\
\hline L.S.D. 0.05\% & 0.076 & 67.9 & L.S.D. 0.05\% & 0.139 & 63.45 \\
\hline
\end{tabular}

4. Effect of Salinity on the Nitrogen Fixation and IAA Production of Two Bacterial Strains

Increasing salinity from 0 to $10 \% \mathrm{NaCl}$ had a negative effect on the nitrogen fixation activity of two selected consortia as indicated in fig. (2). Dramatic decrease in the amount of $\mathrm{N}$ fixed were recorded with increasing the salinity for both consortia. Fixation of nitrogen was inhibited at $6 \% \mathrm{NaCl}$ for consortium B and 4\% for consortium W. Zahran et al. (1995) found that twenty bacterial isolates possessed appreciable nitrogenase activity (acetylene reduction) under non-saline conditions, however at $5 \% \mathrm{NaCl}$ only 
$60 \%$ of the isolates exhibited a high rate of nitrogen-fixing activity and $25 \%$ were completely negative under these conditions. Kouas et al. (2010) reported that salt stress reaching $200 \mathrm{mM} \mathrm{NaCl}$ caused $77 \%$ decrease in the $\mathrm{N}_{2}$ fixing capacity of bacteria as compared to the control.
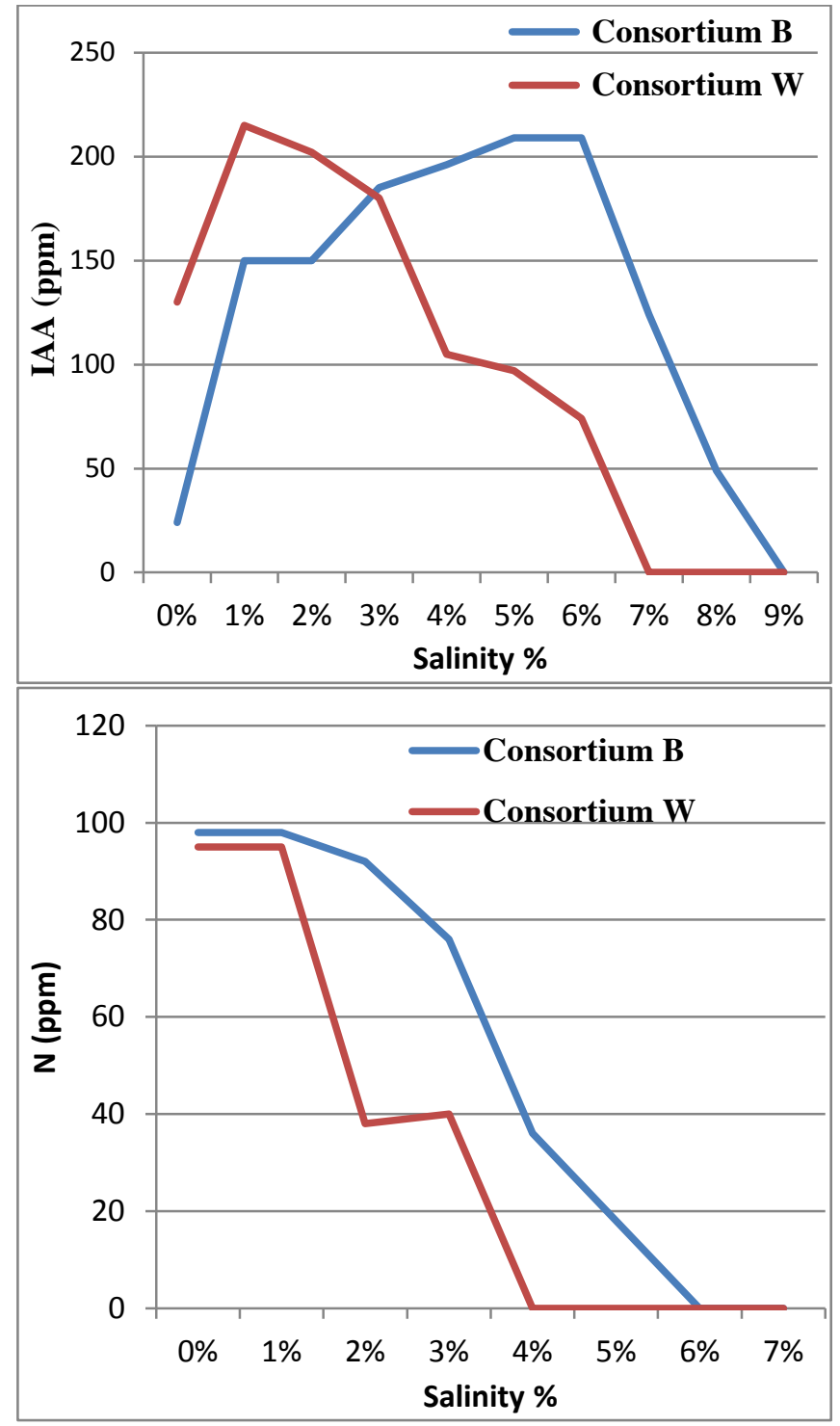

Fig. (2). Effect of salinity on IAA and amount of $\mathrm{N}$ fixed by two bacterial consortia. 
Concerning to IAA, consortium $\mathrm{B}$ exhibited the highest IAA production at both 4 and $5 \% \mathrm{NaCl}$ concentrations recording $209 \mathrm{ppm}$, while consortium $\mathrm{W}$ exhibited the maximum IAA production at $1 \% \mathrm{NaCl}$ recording $215 \mathrm{ppm}$, at the same time, IAA activity had been inhibited at 7\% $\mathrm{NaCl}$ for consortium $\mathrm{W}$ and $9 \%$ for consortium $\mathrm{B}$. These mean that consortium B consisted of barley endophytes was more tolerant to salinity than consortium W consisted of wheat endophytes. Sakhabutdinova et al. (2003) reported that salinity resulted in a progressive decline in the level of IAA in the root system of plants. Arthrobacter siccitolerans, isolated from saline-sodic soils, continued to produce IAA until the EC was $40 \mathrm{dS} \cdot \mathrm{m}^{-1}$, the effects of drought and salinity stresses on variability of IAA production were statistically significant (Soleimani et al., 2015). Under high salt concentrations, naturally present hormones may be suppressed (Afzal et al., 2005). From the previous data, it can be concluded that consortium $W$ was more effective than consortium $\mathrm{B}$ at low salt concentration (1\%), while consortium $\mathrm{B}$ was more effective at high $\mathrm{NaCl}$ concentrations.

\section{Field Experiments}

Field experiments showed that inoculation of seeds with endophytic bacterial consortia significantly increased all the growth parameters of wheat and barley under salt condition as indicated in table (5). For wheat, application of full dose of nitrogen as well as inoculation with consortium W along with half dose of nitrogen achieved the highest significant biological and straw yield/ feddan, followed by the inoculation with consortium B and mixed one as in table (5). At the same time, seed yield/ feddan, plant height, number of tillers and spikes and weight of 1000-grains increased significantly by inoculation with all bacterial consortia, compared to the control regardless the type of consortium used. Enhancement in wheat grain yield (16.3\%) was reported by inoculation of Azotobacter chroococcum strain A103 in wheat (Lakshminarayana et al., 2000). Grain, straw and biological yield of wheat were significantly increased by application of mixed microbial inoculation Azotobacter chrococcum, Azospirillum lipoferum and yeast at salt stress (Elsaid et al., 2014).

Concerning to barley, the maximum enhancement in grain yields reached $28.5 \%$ with the application of full dose of nitrogen and $21.8 \%$ by inoculation with consortium $\mathrm{W}$ along with half dose of nitrogen comparing to control. For other growth and yield traits, all bacterial treatments achieved significant increase regardless the type of bacterial consortia used comparing to control. Significant differences in all yield traits were detected among different genotypes of barley under microbial treatments under saline conditions (Amal and Farag, 2012). These may be due to the bacterial production of different hormones that alleviate the salinity stress. Treating wheat seeds with plant growth regulators like IAA alleviated the growth inhibiting effect of salt stress (Afzal et al., 2005). Gibberellic acid $\left(\mathrm{GA}_{3}\right)$ has 
been reported to be helpful in enhancing wheat and rice growth under saline conditions (Parasher and Varma, 1988).

Table (5). Effect of bacterial consortia on the growth and yield of wheat and barley.

\begin{tabular}{|c|c|c|c|c|c|c|c|c|}
\hline \multicolumn{2}{|r|}{ Treatments } & \multicolumn{7}{|c|}{ Growth parameters } \\
\hline & & $\begin{array}{c}\text { Plant } \\
\text { height } \\
(\mathbf{c m})\end{array}$ & $\begin{array}{l}\text { No. of } \\
\text { tillers } \\
\text { /plant }\end{array}$ & $\begin{array}{l}\text { No. of } \\
\text { Spikes } \\
\text { /plant }\end{array}$ & $\begin{array}{l}\text { 1000-grain } \\
\text { weight } \\
\text { (g) }\end{array}$ & $\begin{array}{c}\text { Grain } \\
\text { yield/plant } \\
\text { ardeb/fed }\end{array}$ & $\begin{array}{c}\text { Straw } \\
\text { yield/plant } \\
\text { ardeb/fed }\end{array}$ & $\begin{array}{l}\text { Biological } \\
\text { yield/plant } \\
\text { ardeb/fed }\end{array}$ \\
\hline & & \multicolumn{6}{|c|}{ Wheat } & \\
\hline Half & Control & $69.1 \mathrm{~b}$ & $4.1 \mathrm{~b}$ & $3.4 \mathrm{c}$ & $33.2 \mathrm{~b}$ & $10.95 b$ & $10.38 \mathrm{~b}$ & $21.33 \mathrm{~b}$ \\
\hline dose & Consortium W & $73.6 \mathrm{a}$ & $4.4 \mathrm{a}$ & $3.6 \mathrm{a}$ & $35.7 \mathrm{a}$ & $14.72 \mathrm{a}$ & $12.5 \mathrm{a}$ & $27.23 \mathrm{a}$ \\
\hline \multirow[t]{2}{*}{ of $\mathbf{N}$} & Consortium B & $73.6 \mathrm{a}$ & $4.3 \mathrm{a}$ & $3.5 \mathrm{~b}$ & $35.6 \mathrm{a}$ & $13.08 \mathrm{a}$ & $11.16 \mathrm{~b}$ & $24.24 \mathrm{ab}$ \\
\hline & Mixture & $73.5 \mathrm{a}$ & $4.3 \mathrm{a}$ & $3.6 \mathrm{a}$ & $36.1 \mathrm{a}$ & $13.93 \mathrm{a}$ & $11.30 \mathrm{ab}$ & $25.24 \mathrm{ab}$ \\
\hline \multicolumn{2}{|r|}{ Full dose of $\mathbf{N}$} & $73.9 \mathrm{a}$ & $4.6 \mathrm{a}$ & $3.9 \mathrm{a}$ & $36.1 \mathrm{a}$ & $14.86 \mathrm{a}$ & $13.01 \mathrm{a}$ & $27.87 \mathrm{a}$ \\
\hline \multicolumn{2}{|r|}{ L.S.D. $0.05 \%$} & 4.73 & 0.47 & 0.619 & 0.569 & 2.24 & 1.789 & 5.05 \\
\hline \multicolumn{9}{|c|}{ Barley } \\
\hline \multirow{4}{*}{$\begin{array}{l}\text { Half } \\
\text { dose } \\
\text { of N }\end{array}$} & Contro & $63.2 \mathrm{~b}$ & $8.6 \mathrm{c}$ & $5.4 \mathrm{~b}$ & $40.7 \mathrm{~b}$ & $12.44 \mathrm{c}$ & $11.13 \mathrm{~b}$ & $23.58 \mathrm{c}$ \\
\hline & Consorti & $66.0 \mathrm{a}$ & $9.3 \mathrm{ab}$ & $5.8 \mathrm{a}$ & $42.6 \mathrm{a}$ & $15.18 \mathrm{a}$ & $14.56 \mathrm{a}$ & $29.74 a$ \\
\hline & Consortium B & $66.0 \mathrm{a}$ & $9.2 \mathrm{~b}$ & $5.8 \mathrm{a}$ & $42.5 \mathrm{a}$ & $14.31 \mathrm{~b}$ & $12.88 \mathrm{a}$ & $27.19 b$ \\
\hline & Mixture & $66.2 \mathrm{a}$ & $9.3 \mathrm{ab}$ & $5.8 \mathrm{a}$ & $42.6 \mathrm{a}$ & $14.18 b$ & $14.12 \mathrm{a}$ & $28.31 \mathrm{ab}$ \\
\hline \multirow{2}{*}{\multicolumn{2}{|c|}{$\frac{\text { Full dose of } \mathbf{N}}{\text { L.S.D. } 0.05 \%}$}} & $67.4 \mathrm{a}$ & $9.8 \mathrm{a}$ & $5.9 \mathrm{a}$ & $43.2 \mathrm{a}$ & $15.99 \mathrm{a}$ & $13.68 \mathrm{a}$ & $29.68 \mathrm{a}$ \\
\hline & & 4.65 & 0.559 & 0.463 & 0.938 & 1.49 & 1.82 & 2.02 \\
\hline
\end{tabular}

Nitrogen content of wheat and barley seeds increased significantly under salt condition by application of full dose of nitrogen as well as by inoculation with bacterial consortium $\mathrm{W}$ along with half dose of nitrogen, followed by other bacterial consortia, compared to control as in table (6). Significant increase in the nitrogen content of straw was detected by application of full dose of nitrogen or inoculation with bacterial consortia and half dose of nitrogen with no differences among treatments were detected. The maximum $\mathrm{N}$ uptake of seed and straw of wheat and barley was observed with the application of full dose of nitrogen. Among bacterial inoculation, while consortium $\mathrm{W}$ was the most effective one in $\mathrm{N}$ uptake followed by other treatments, consortium B was less effective one compared to control. Several of associative and endophytic diazotrophic bacteria were reported to improve nutrient uptake (Richardson et al., 2009 and Saha et al., 2013). Bacterial treatments have been shown to have a positive influence on plant nutrition under salt-stressed conditions (Mahajan and Tuteja, 2005).

Concerning to availability of $\mathrm{N}$ in rhizosphere of both wheat and barley, application of full dose of nitrogen achieved the highest significant increase, followed by that of bacterial inoculation regardless the type of bacterial consortia applied. Application of microorganisms as inoculants enhances the availability of nutrients NPK in soil and decreases the 
requirement of chemical fertilizers (Cakmakci et al., 2007). This increase in the availability of $\mathrm{N}$ may be attributed to the fixation of nitrogen. Nonsymbiotic heterotrophic bacteria Azotobacter spp. capable of fixing an average $20 \mathrm{~kg} \mathrm{~N} / \mathrm{ha} /$ per year (Bashan, 1991). Microorganisms tolerating high concentration of salt in the soil and yet capable of fixing nitrogen are of importance in increasing its fertility (Jadhav et al., 2010).

Table (6). Effect of endophytic bacterial consortia on nitrogen constituents of wheat and barley.

\begin{tabular}{|c|c|c|c|c|c|c|c|c|c|c|c|}
\hline \multirow{3}{*}{\multicolumn{2}{|c|}{ Treatments }} & \multicolumn{5}{|c|}{ Wheat } & \multicolumn{5}{|c|}{ Barley } \\
\hline & & \multicolumn{2}{|c|}{$\mathbf{N} \%$} & \multicolumn{2}{|c|}{$\begin{array}{l}\text { N uptake } \\
\text { kg/feddan }\end{array}$} & \multirow{2}{*}{$\begin{array}{c}\mathbf{N} \\
\text { available } \\
\text { in soil } \\
(\mathrm{ppm})\end{array}$} & \multicolumn{2}{|c|}{$\mathbf{N \%}$} & \multicolumn{2}{|c|}{ N uptake } & \multirow{2}{*}{$\begin{array}{c}\mathbf{N} \\
\text { available } \\
\text { in soil }\end{array}$} \\
\hline & & Straw & Seed & Straw & Seed & & Straw & Seed & Straw & Seed & \\
\hline \multirow{4}{*}{$\begin{array}{l}\text { Half } \\
\text { dose } \\
\text { of } N\end{array}$} & Control & $0.49 \mathrm{~b}$ & $2.12 b$ & $3.81 \mathrm{c}$ & $17.4 \mathrm{c}$ & $255 \mathrm{~d}$ & $0.50 \mathrm{~b}$ & $2.37 \mathrm{c}$ & $4.71 \mathrm{c}$ & $25.2 \mathrm{c}$ & $274 d$ \\
\hline & $\begin{array}{l}\text { Consortium } \\
\text { W }\end{array}$ & $0.51 \mathrm{a}$ & $2.23 \mathrm{ab}$ & $4.78 \mathrm{a}$ & $24.6 \mathrm{a}$ & $322 b$ & $0.53 \mathrm{a}$ & $2.42 b$ & $6.61 \mathrm{a}$ & $31.9 \mathrm{a}$ & $298 \mathrm{c}$ \\
\hline & $\begin{array}{l}\text { Consortium } \\
\text { B }\end{array}$ & $0.53 \mathrm{a}$ & $2.21 \mathrm{ab}$ & $4.43 b$ & $21.6 \mathrm{~b}$ & $298 \mathrm{c}$ & $0.52 \mathrm{a}$ & $\begin{array}{c}2.41 \mathrm{~b} \\
\mathrm{c}\end{array}$ & $5.74 \mathrm{~b}$ & $29.5 b$ & $296 c$ \\
\hline & Mixture & $0.52 \mathrm{a}$ & $2.23 \mathrm{ab}$ & $4.40 \mathrm{~b}$ & $23.3 \mathrm{a}$ & $325 b$ & $0.53 \mathrm{a}$ & $\begin{array}{c}2.41 b \\
c\end{array}$ & $6.41 \mathrm{a}$ & $29.3 b$ & $320 b$ \\
\hline \multicolumn{2}{|c|}{ Full dose of $\mathrm{N}$} & $0.53 \mathrm{a}$ & $2.24 \mathrm{a}$ & $5.17 \mathrm{a}$ & $24.9 \mathrm{a}$ & $346.5 \mathrm{a}$ & $0.54 \mathrm{a}$ & $2.48 \mathrm{a}$ & $6.33 \mathrm{a}$ & $33.9 \mathrm{a}$ & $334 a$ \\
\hline \multicolumn{2}{|c|}{ L.S.D. $0.05 \%$} & 0.038 & 0.1 & 0.51 & 1.54 & 17.62 & 0.04 & 0.041 & 0.55 & 2.02 & 9.27 \\
\hline
\end{tabular}

As in table (7), mineral fertilization of wheat and barley with full dose of nitrogen recorded the highest microbial count in the rhizosphere region, followed by other treatments of nitrogen fixer consortia. It is assumed that microbial population in the soil was correlated with higher nitrogen concentrations in the roots due to higher levels of extractable mineral nitrogen in the soil. Increased nitrogen fertilization has been reported to increase the numbers of bacteria in the rhizosphere (Vuurde and Van, 1978 and Liljeroth et al., 1990). These results were parallel with that of dehydrogenase activity in soil. Abou-Aly (2005) found that the combined inoculation with Azospirillum sp. and Bacillus sp. increased the dehydrogenase at all growth plant stages. Inoculation with any of endophytic bacterial consortia had a positive effect on the counts of nitrogen fixers in the rhizoshere region compared to uninoculated ones. 
Table (7). Effect of endophytic bacterial consortia on microbiological characteristics of wheat and barley rhizosphere.

\begin{tabular}{|c|c|c|c|c|c|c|c|c|c|}
\hline \multirow{3}{*}{\multicolumn{2}{|c|}{ Treatments }} & \multicolumn{8}{|c|}{ Microbiological characteristics } \\
\hline & & \multicolumn{2}{|c|}{$\begin{array}{l}\text { Total microbial } \\
\text { count*10 } 10^{5} \mathrm{CFU} \\
/ \mathrm{g} \text { dry soil }\end{array}$} & \multicolumn{2}{|c|}{$\begin{array}{c}\text { Azotobacter } \\
\text { count*10 }{ }^{3} \mathrm{CFU} \\
/ \mathrm{g} \text { dry soil }\end{array}$} & \multicolumn{2}{|c|}{$\begin{array}{c}\text { Azospirillum } \\
\text { count* } \mathbf{1 0}^{3} \text { cells } \\
\text { /g dry soil }\end{array}$} & \multicolumn{2}{|c|}{$\begin{array}{c}\text { Dehydrogenase } \\
\text { ( } \mu \mathrm{g} \text { TPF/g } \\
\text { dry soil/24 h) }\end{array}$} \\
\hline & & Wheat & Barley & Wheat & Barley & Wheat & Barley & Wheat & Barley \\
\hline Half & Control & 76 & 78 & 2.1 & 1.4 & 1.7 & 1.8 & $127 \mathrm{~b}$ & $112 \mathrm{~b}$ \\
\hline dose & Consortium W & 131 & 110 & 3.4 & 2.3 & 1.7 & 1.6 & $192 \mathrm{a}$ & $165 \mathrm{a}$ \\
\hline \multirow[t]{2}{*}{ of $\mathbf{N}$} & Consortium B & 110 & 114 & 1.9 & 2.3 & 2.3 & 2.4 & $198 \mathrm{a}$ & $159 \mathrm{a}$ \\
\hline & Mixture & 96 & 105 & 4.1 & 1.8 & 2.1 & 2.2 & $202 \mathrm{a}$ & $161 \mathrm{a}$ \\
\hline \multirow{2}{*}{\multicolumn{2}{|c|}{ Full dose of $N$}} & 88 & 85 & 2.1 & 1.3 & 1.8 & 1.8 & $128 b$ & $116 \mathrm{~b}$ \\
\hline & & \multicolumn{4}{|c|}{ L.S.D. $0.05 \%$} & & & 23.1 & 21.4 \\
\hline
\end{tabular}

\section{CONCLUSION}

Besides their capability of fixing nitrogen, endophytic diazotrophic bacteria produce plant growth hormones under salinity stress. The efficiency of the endophytic consortia, as plant growth promoters, depends on their bacterial activities and not to the host plant type. Bacterial consortia of salt tolerant endophytic diazotrohs those producing phytohormone are recommend to alleviate salt stress of wheat and barley grown under conditions of soil salinity.

\section{REFERENCES}

Abou-Aly, H.E. (2005). Stimulatory effect of some yeast applications on response of tomato plants to inoculation with biofertilizers. Annals of Agriculture Science, Moshtohor, 43 (2): 595-609.

Afzal, I., S. Basra and A. Iqbal (2005). The effect of seed soaking with plant growth regulators on seedling vigor of wheat under salinity stress. J. Stress Physiol. Biochem., 1 (1): 6-14.

Amal, M. Omer and H.I.A. Farag (2012). Biological activity of phosphate dissolving bacteria and their effect on some genotypes of barley production. Journal of Applied Sciences Research, 8 (7): 3478-3490.

Baca, B. and C. Elmerich (2007). In "Microbial Production of Plant Hormones". (Elmerich, C. and Newton W. Eds). Associative and Endophytic Nitrogen-fixing Bacteria and Cyanobacterial Associations. Dordrecht, Springer, p. 113-143.

Bano, Q., I.N. Lyas, A. Bano, N. Zafar, A. Akram and F. Hassan (2013). Effect of Azospirillum inoculation on maize (Zea mays L.) under drought stress. Pak. J. Bot., 45 (S1): 13-20. 
Bashan, Y. (1991). Changes in membrane potential of intact soybean root elongation zone cells induced by Azospirillum brasilense. Can. J. Microbiol., 37: 958-963.

Bowman, D.C., D.A. Devitt and W.W. Miller (2006). The effect of moderate salinity on nitrate leaching from bermudagrass turf: a lysimeter study. Water Air and Soil Pollution, 175: 49-60.

Bremner, J.M. and C.S. Mulvaney (1982). In "Nitrogen". (Page, A.L., R.H. Miller and D.R. Keeney Eds.). Methods of Soil Analysis. Part 2, Chemical and Microbiological Properties. Agronomy 9, Soc. Agron., Madison, Wisconsin, p. 595-624.

Cakmakci, R., M.F. Donmez and U. Erdogan (2007). The effect of plant growth promoting rhizobacteria on barley seedling growth, nutrient uptake, some soil properties, and bacterial counts. Turk. J. Agr. For., 31: 189-199.

Calderini, D.F. and G.A. Slafer (1998). Changes in yield and yield stability in wheat during the 20th century. Field Crop Res., 57: 335-347.

Cocking, E.C. (2003). Endophytic colonization of plant roots by nitrogenfixing bacteria. Plant and Soil, 252 (1): 169-175.

Dalton, D.A. and S. Kramer (2006). In "Plant Associated Bacteria". Springer, The Netherlands, p. 105-130.

Denise, K.Z., P. Lambrecht, N.B. Harris, Z. Feng, D. Kuczmarski, H. Phyllis, A. Carol, A. Arunakumari, R.G. Barletta and A.K. Vidaver (2002). Isolation and characterization of endophytic colonizing bacteria from agronomic crops and prairie plants. Appl. Environ. Microbiol., 68 (5): 2198-2208.

Egamberdieva, D. (2009). Alleviation of salt stress by plant growth regulators and IAA producing bacteria in wheat. Acta Physiol. Plant., 31: 861-864.

Ehmann, A. (1977). The Van Urk-Salkowski reagent-a sensitive and specific chromogenic reagent for silica gel thin-layer chromatographic detection and identification of indole derivatives. Journal of Chromatography, 132: 267-276.

Elsaid, M.A., Omer A.M. and H.I.A. Farag (2014). Using of biofertilizers and their effects on some Bread wheat (Triticum saetivum) varieties productions under desert condition. Egyptian Journal of Agriculture, 155-164.

Figueiredo, M.V.B., H.A. Burity, C.R. Martınez and C.P. Chanway (2008). Alleviation of drought stress in the common bean (Phaseolus vulgaris L.) by co-inoculation with Paenibacillus polymyxa and Rhizobium tropici. Appl. Soil Ecol., 4: 182-188.

Friedel, J.K., K. Molter and W.R. Fischer (1994). Comparison and improvement of methods for determing soil dehydrogenase activity using triphenyl chloride and iodonitrotetrazolium chloride. Biol. Fertil. Soils, 18: 291-296.

Egyptian J. Desert Res., 67, No. 1, 210-229 (2017) 
Graham, H.D. and J.H.M. Henderson (1960). Reaction of gibberellic acid and gibberellins with Folin-Wu phosphomolybdic acid reagent and its use for quantitative assay. Plant Physiology, 36 (4): 405.

Gul, B., M.A. Khan and D.J. Weber (2000). Alleviation salinity and dark enforced dormancy in Allenrolfea occidentalis seeds under various thermo periods. Aust. J. Bot., 48: 745-752.

Han, S.O. and P.B. New (1998).Variation in nitrogen fixing ability among natural isolates of Azospirillum. Microb. Eco., 36: 193-200.

Hardy, R., R.C. Burns and R.D. Holsten (1973). Applications of the acetylene-ethylene assay for measurement of nitrogen fixation. Soil Biology and Biochemistry, 5 (1): 47-81.

Hoagland, D.R. and D. Arnon (1950). The water-culture method for growing plants with soil. Calif. Agric. Exp. Sta. Cir., 347.

Jadhav, G.G., D.S. Salunkhe, D.P. Nerkar and R.K. Bhadekar (2010). Isolation and characterization of salt-tolerant nitrogen-fixing microorganisms from food. J. Eur. Asia. Bio. Sci., 4: 33-40.

Khan, M.A., B. Gul and D.J. Weber (2004). Action of plant growth regulators and salinity on seed germination of Ceratoides lanata. Can. J. Bot., 82: 37-42.

Khush, G.S. (1999). Green revolution: preparing for the $21^{\text {st }}$ century. Genome. 42 (4): 646-55.

Kouas, S., T. Slatni, I.B. Salah and C. Abdelly (2010). Eco-physiological responses and symbiotic nitrogen fixation capacity of salt-exposed Hedysarum carnosum plants. J. Afr. Biotechnol., 9 (44): 7462-7469.

Kumar, B. and B. Singh (1996). Effect of plant hormones on growth and yield of wheat irrigated with saline water. Ann. Agri. Res., 17: 209212.

Lakshminarayana, K.R., B. Shukla, S.S. Sindhu, P. Kumari, N. Narula and R.K. Sheoran (2000). Analogue-resistant mutants of Azotobacter chroococcum derepressed for nitrogenase activity and early ammonia excretion having potential as inoculants for cereal crops. Indian J. Expt. Biol., 38: 373-378.

Lee, Y., W. Mohamed, F. Dahab and I. Bogardi (1992). Nitrate risk management under uncertainty. Journal of Water Resources Planning and Management, 118 (2): 151-165.

Liljeroth, E., J.A. Veen and H.J. Miller (1990). Assimilate translocation to the rhizosphere of two wheat cultivars and subsequent utilization by rhizosphere microorganisms at two soil nitrogen concentrations. Soil Biology and Biochemistry, 456: 472.

Mahajan, S. and N. Tuteja (2005). Cold, salinity and drought stresses: an overview. Archives of Biochemistry and Biophysics, 444 (2): 139 158. 
Mascarua, M.A., R.V. Gonjzalez and J. Caballero (1998). Acetylene reduction and indoleacetic acid production by Azospirillum isolates from cactaceous plants. Plant Soil, 106: 91-95.

Parasher, A. and S.K. Varma (1988). Effect of pre-sowing seed soaking in gibberellic acid on growth of wheat (Triticum aestivum L.) under different saline conditions. Indian J. Biol. Sci., 26: 473-475.

Pathak, K., H. Keharia and A.C. Kharkwal (2009). Im "Isolation, Cultivation and in Planta Visualization of Bacterial Endophytes from Hanging Roots of Banyan tree". Symbiotic Fungi, Principle and Practice. Soil Biology Series Book (Verma, A. and A.C. Kharkwal Eds.). Springer link-Verlag, 18: 211-227.

Patriquin, D.G. and J. Dobereiner (1978). Light microscopy observations of tetrazolium-reducing bacteria in the endorhizosphere of maize and other grasses in Brazil. Can. J. Microbiol., 24: 724-742.

Pessarakli, M. and T.C.Tucker (1988). Dry matter yield and nitrogen-15 uptake by tomatoes under sodium chloride stress. Soil Sci. Soc. Am. J., 52: 698-700.

Ravikumar, S., G. Ramanathan, N. Suba and L. Jeyaseli (2002). Quantifikasi of halophilic Azospirillum from mangroves. Indian Journal of Marine Sciences, 31 (2): 157-160.

Reinhold-Hurek B. and T. Hurek (1998). Interactions of gramineous plants with Azoarcus spp. and other diazotrophs: identification, localization and perspectives to study their function. Crit. Rev. Plant Sci., 17: $29-54$.

Richardson, A.E., J. Barea, A.M.C. Neill and P. Combaret (2009). Acquisition of phosphorus and nitrogen in the rhizosphere and plant growth promotion by microorganisms. Plant and Soil, 321: 305-339.

Saha, R.N., R.S. Donofrio and L.L. Bestervelt (2013). Microbial siderophores: a mini review. Journal of Basic Microbiology, 53: 303-317.

Sakhabutdinova, A.R., D.R. Fatkhutdinova, M.V. Bezrukova and F.M. Shakirova (2003). Salicylic acid prevents the damaging action of stress factors on wheat plants. Bulg. J. Plant Physiol. (Special issue), 314-319.

Samasegaran, P.H., Hoben and J. Halliday (1982). In "The NIFTAL (Nitrogen Fixation in Tropical Agricultural Legumes) Manual for Methods in Legume-Rhizobium Technology". US Agency for International Development, College of Tropical Agriculture and Resources, University of Hawai, USA.

Snedecor, G.W. and W.G. Cochran, (1990). In "Statistical Methods". $8^{\text {th }}$ Edition. Iowa State Univ. Press, Ames, Iowa, USA.

Soleimani, R., H. Tofighi and H. Alikhani (2015).The effect of drought and salinity tensions on IAA production in isolated bacteria from saline and saline-sodic soils. Nova Biologica Reperta, 2 (3):186-198.

Egyptian J. Desert Res., 67, No. 1, 210-229 (2017) 
Somasegaran, P. and H.J. Hoben (1985). Methods in legume-Rhizobium technolog. Paia, Maui, University of Hawaii NifTAL Project and MIRCEN, Department of Agronomy and Soil Science, Hawaii Institute of Tropical Agriculture and Human Resources, College of Tropical Agriculture and Human Resources. 365 pp.

Stoskopf, N.C. (1985). In "Cereal Grain Crops". Reston Publishing Company Inc., Reston, Virginia.

Thekkiniath, J.1., S. Paul, P. Dureja and D.W. Dhar (2010). Physiological studies on endo-rhizospheric establishment of Azotobacter chroococcum in wheat. J. Basic Microbiol., 250 (3): 266-73.

Villa-Castorena, M., A.L. Ulery, E.A. Catalan-Valencia and M.D. Remmenga (2003). Salinity and nitrogen rate effects on the growth and yield of chile pepper plants. Soil Sci. Soc. Am. J., 67: 17811789.

Vuurde, J. and W.L. Van (1978). The rhizosphere microflora of wheat grown under controlled conditions. Plant and Soil, 50: 447-460.

Waller, R.A. and B.D. Duncan (1969). A way for the symmetric multiple comparison problem. Amer. Stat. Assoc. J., 3: 1485-1503.

Wolfram, R.U.1. (2012). Salinity and nitrogen nutrition. SalinityEnvironment-Plants- Molecules, 229-248.

Zahran, H.H., M.S. Ahmad and A. Eman (1995). Isolation and characterization of nitrogen-fixing moderate halophilic bacteria from saline soils of Egypt. Journal of Basic Microbiology, 42: 646-655. 


\section{إستخدام مثبتات النيتروجين الداخلية بالنبات لتحسين إنتاجية بعض النجيليات

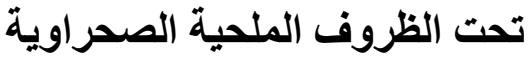

أمل محمد عمر سنالم

قسم خصوبة وميكروبيولوجيا الأر اضى، مركز بحوث الصحر اء، المطرية، القاهرة، مصر

تهدف الدراسة الحالية إلى تكوين وتقيبم الإتحادات البكتيرية المختلفة من البكتيريـا الداخلية

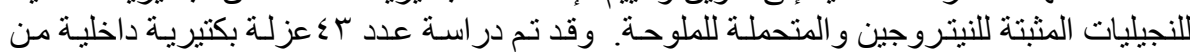

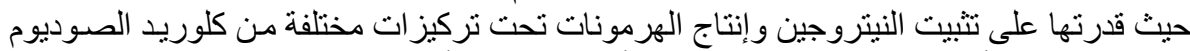

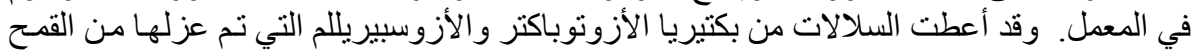

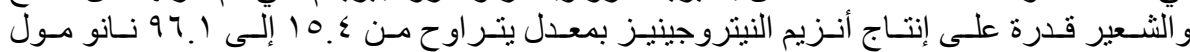

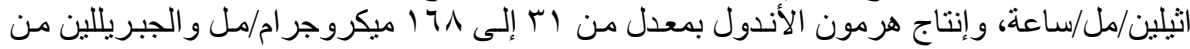

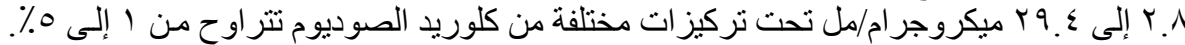

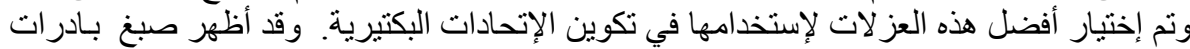

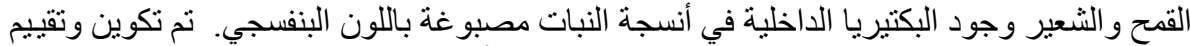

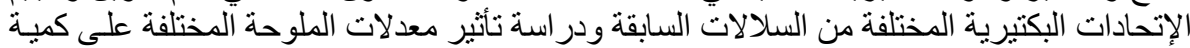

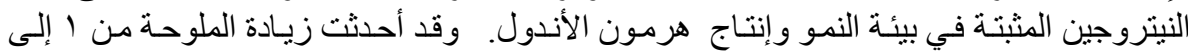

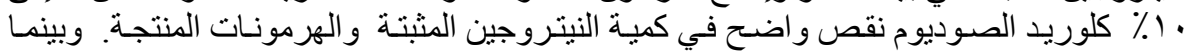

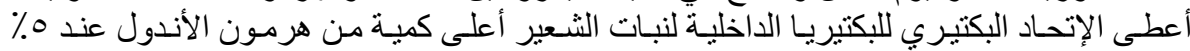

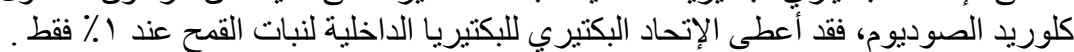

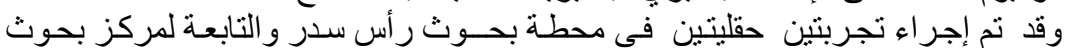

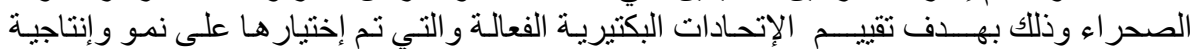

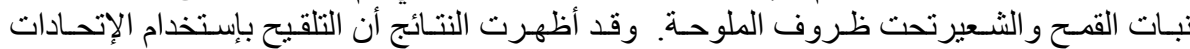

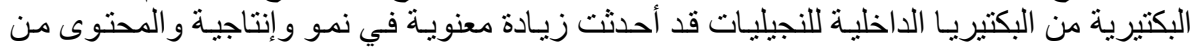

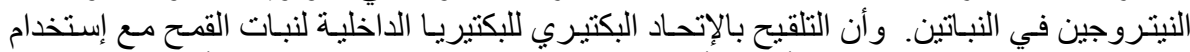

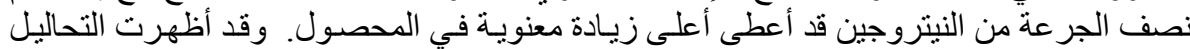

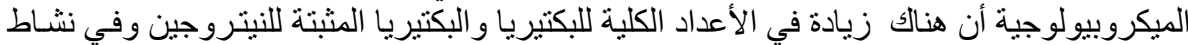
أنزيم الديهيدروجينيز بمنطقة الريزوسفير. لادئ.

Egyptian J. Desert Res., 67, No. 1, 210-229 (2017) 